\title{
Pengembangan Buku Ajar Kimia Kelas X Berbasis Reduksi Didaktik: Uji Kelayakan di SMA Negeri Kota Banjarmasin
}

\author{
Arif Sholahuddin \\ Prodi Pendidikan Kimia FKIP Unlam Banjarmasin, e-mail: arifchemist@ymail.com
}

\begin{abstract}
Abstrak: Penelitian dengan desain Research and Development tahap pertama ini bertujuan untuk menghasilkan buku ajar kimia kelas $X$ berbasis reduksi didaktik yang layak digunakan dalam pembelajaran. Sampel diambil secara stratified random sampling sebanyak 3 sekolah dari 13 SMA Negeri di Banjarmasin. Data penelitian dianalisis secara deskriptif berdasarkan indikator kelayakan yaitu buku ajar dianggap layak jika skor validasi maupun respon siswa terhadap buku ajar dalam kategori baik atau sangat baik dan sebanyak $80 \%$ atau lebih siswa mencapai tingkat penguasaan $\geq 65$. Hasil penelitian menunjukkan bahwa buku ajar layak digunakan karena validitas buku ajar dalam kategori sangat baik, respon siswa terhadap buku ajar dalam kategori baik dan ketuntasan belajar siswa secara klasikal mencapai 80,2\%. Selanjutnya untuk meningkatkan kualitas buku ajar dan tingkat penguasaan siswa, guru perlu meningkatkan kemandirian belajar siswa, membimbing siswa agar mengikuti panduan penggunaan buku, melakukan ujicoba lanjut yang melibatkan sampel lebih luas dan mengembangkannya menjadi buku ajar interaktif.
\end{abstract}

Kata kunci: buku ajar, reduksi-didaktik, interaktif, kimia

\begin{abstract}
This first phase of research and development is to produce chemistry instructional book for class $\mathrm{X}$ based on reduction-didactic which is feasible used in teaching and learning. The sample, three schools of 13 State Senior High Schools of Banjarmasin, are drawn using stratified random sampling. The collected research datas are analyzed descriptively based on instructional book feasibility indicators, where instructional book is considered as a feasible book for teaching and learning if both validation and student's responses score to it in good or very good category; classically, $80 \%$ of students or more achieve mastery level of $\geq 65$. This research show that the instructional book is feasible because it's validity is very good, student's responses is good and classically, students' mastery level reaches $80.2 \%$. Futhermore, in order to increase more qualified instructional book and students' mastery level, hence it's need to increase the student's self-learning; to direct students to follow the instructional book guidelines, to conduct futher field test that involve a wide range of samples and develop it as an interactive instructional book.
\end{abstract}

Key words: instructional book, reduction-didactic, interactive, chemistry

\section{Pendahuluan}

Menurut Nisa dkk. (2006) bahwa penguasaan materi pembelajaran kimia siswa SMAN di Banjarmasin masih tergolong rendah, yakni $50,84 \%$. Berdasarkan tingkat kesulitannya dimulai dari yang paling mudah adalah (1) struktur atom dan sistem periodik unsur $(25,43 \%),(2)$ perhitungan kimia $(39,55 \%)$, (3) ikatan kimia $(47,49 \%),(4)$ tata nama senyawa dan persamaan reaksi $(49,72 \%)$, (5) larutan elektrolit dan larutan non elektrolit $(55,38 \%)$, (6) hidrokarbon dan minyak bumi $(61,36 \%)$ dan (7) reaksi redoks $(65,24 \%)$. Faktor penyebab kesulitan antara lain sebanyak $53 \%$ siswa saja yang mempelajari materi pelajaran sebelum dan sesudah diajarkan; $76 \%$ siswa kesulitan akibat materi kimia bersifat abstrak dan banyak hitungan; metode ceramah masih mendominasi kegiatan belajar $72,73 \%$ dan penggunaan media masih minim $51,36 \%$.

Selanjutnya, Middlecamp \& Kean (1985) dan Arifin (1995), terdapat beberapa penyebab terjadinya hambatan dalam mempelajari ilmu kimia yaitu kesulitan mahami istilah, kesulitan memahami konsep kimia dan kesulitan matematis. Kesulitan yang paling banyak dialami oleh siswa adalah memahami konsep akibat banyak konsep 
kimia yang bersifat abstrak dan memerlukan kemampuan berfikir formal untuk memahaminya. Sementara tingkat berfikir formal siswa masih relatif belum memadai. Misalnya kesulitan menggambarkan bagaimana terjadinya reaksi kimia, bagaimana elektron dilepaskan atau digunakan bersama ketika atom-atom melakukan ikatan kimia, bagaimana reaksi berlangsung di katoda atau anoda?

Kesulitan-kesulitan tersebut dapat diatasi dengan reduksi didaktik terhadap materi kimia. Reduksi Didaktik adalah mengurangi tingkat kesulitan materi pengajaran baik secara kualitatif ataupun kuantitatif dengan jalan materi tersebut dibuat sesederhana mungkin sehingga lebih mudah dipelajari oleh peserta didik (Anwar, 1995).

Proses reduksi didaktik haruslah mendasarkan pada tingkat perkembangan psikis dan umur peserta didik, sebab setiap anak didik pada tingkat perkembangan tertentu mempunyai cara tersendiri yang khas didalam memandang, menggambarkan dan menjelaskan konsep untuk mengurangi tingkat kesulitan materi pelajaran tanpa mengurangi tingkatan cakupan ilmiahnya. Hal ini menunjukkan bahwa aspek psikologi belajar yaitu intelligensi dan psikologi perkembangan memegang peranan penting untuk melakukan reduksi didaktik dalam pembelajaran kimia.

Reduksi didaktik materi kimia dapat dilakukan melalui penyederhanan istilah, penyederhanaan konsep, penggunaan simbul, gambar, dan ilustrasi yang mudah dipahami oleh siswa, yang selanjutnya diterapkan pada sajian informasi buku ajar. Beberapa hasil penelitian menemukan bahwa pendekatan Reduksi Didaktik dalam proses belajar mengajar dapat meningkatkan pemahaman siswa terhadap konsep kimia antara lain materi struktur atom, sistem periodik unsur dan ikatan (Anwar, 1996), dan materi laju reaksi (Febrianti, 2005)

Faktor siswa yang tidak mempelajari materi pelajaran di rumah sebagaimana dilaporkan Nisa (2006) dapat disebabkan sukarnya memahami konsep kimia akibat materi kimia bersifat abstrak dan banyak hitungan atau informasi dari pustaka yang sukar dipahami. Meskipun perkembangan buku-buku pelajaran cukup pesat dengan cetakan yang menarik, namun sajian informasi masih cukup berat apalagi bagi siswa kelas pemula atau kelas
$X$ yang memiliki pengalaman belajar kimia terbatas. Selain itu berdasarkan hasil kajian Bank Dunia menunjukkan daya beli siswa maupun sekolah terhadap buku masih sangat rendah khususnya di daerah-daerah (Indrianto, 2002). Hasil visitasi terbatas terhadap 8 SMA/SMK (BAP S/M, 2008) pada 3 Kabupaten di Kalimantan Selatan menunjukkan tidak satupun sekolah yang mempunyai perpustakaan standar. Dengan demikian pengadaan buku ajar yang sederhana, mudah dipahami, menarik minat baca siswa dan dengan harga yang murah merupakan persoalan yang penting.

Buku ajar merupakan salah satu media dalam pembelajaran yang berisi informasi materi pelajaran, gambar-gambar dan penjelasan konsep. Sedangkan buku pada umumnya hanya mengasumsikan minat dari pembaca, ditulis terutama untuk digunakan oleh guru, dirancang untuk dipasarkan secara luas, tidak menjelaskan tujuan intruksional, disusun secara linier, struktur berdasarkan logika bidang ilmu (content), belum tentu memberikan latihan dan tidak mengantisifasi kesukaran belajar siswa, belum tentu memberikan rangkuman, gaya penulisan naratif, materi sangat padat, tidak mempunyai mekanisme untuk mengumpulkan umpan balik dari pemakai dan tidak memberikan saran-saran cara mempelajari materi didalamnya (Suparman, 1993).

Seiring perkembangan teknologi informasi, buku ajar ini dapat dikembangkan menjadi buku ajar interaktif menggunakan software-software media seperti macroflash media, macromedia authorware dan lain-lain. Dengan memanfaatkan software ini dapat dibuat antara lain modul atau buku ajar yang interaktif dengan disisipi musik, animasi, film dan lain sebagainya sehingga menjadi gabungan yang menarik dan mudah dipahami. Dengan demikian penggunaan buku ajar berbasis reduksi didaktik-interaktif diharapkan akan lebih memberi kesempatan bagi siswa untuk belajar menurut kecepatan masing-masing, memberi kesempatan kepada siswa untuk belajar lebih mandiri, meningkatkan motivasi dan pemahaman siswa terhadap konsep kimia.

Masalah yang dikaji dalam penelitian ini adalah bagaimana kelayakan buku ajar kimia kelas X SMA berbasis reduksi didaktik untuk pembelajaran ditinjau dari variabel validitas, 
respon siswa terhadap buku ajar dan ketuntasan belajar siswa?

Penelitian ini bertujuan untuk menghasilkan buku ajar kimia kelas X SMA berbasis reduksi didaktik yang layak digunakan dalam pembelajaran berdasarkan variabel validitas, respon siswa terhadap buku ajar dan ketuntasan belajar siswa.

\section{Kajian Literatur Buku Ajar}

Bahan ajar adalah segala bentuk bahan yang digunakan untuk membantu guru/instruktur dalam melaksanakan kegiatan belajar mengajar di kelas, baik berupa bahan tertulis seperti hand out, buku, modul, lembar kerja siswa, brosur, leaflet, wallchart, maupun bahan tidak tertulis seperti video/film, VCD, radio, kaset, CD audio, foto, gambar, model/maket, $C D$ interaktif berbasis computer dan internet. Bahan ajar dalam bentuk tertulis berupa materi yang harus dipelajari siswa sebagai sarana untuk mencapai standar kompetensi dan kompetensi dasar. Materi pembelajaran (instructional materials) tersebut berupa pengetahuan, keterampilan, dan sikap yang harus diajarkan oleh guru dan harus dipelajari oleh siswa untuk mencapai standar kompetensi dan kompetensi dasar. Jenis materi pelajaran dapat berupa fakta, konsep, prinsip, prosedur, dan sikap atau nilai (Depdiknas, 2003).

Beberapa bahan ajar yang diususun secara sistematik berdasarkan urutan tertentu untuk mencapai kompetensi membentuk sebuah buku. Terdapat dua jenis buku yakni buku teks dan buku ajar. Buku teks yang digunakan pada pembelajaran pada umumnya hanya mengasumsikan minat dari pembaca, ditulis terutama untuk digunakan oleh guru, dirancang untuk dipasarkan secara luas, tidak menjelaskan tujuan intruksional, disusun secara linier, struktur berdasarkan logika bidang ilmu (content), belum tentu memberikan latihan tidak mengantisifasi kesukaran belajar siswa, belum tentu memberikan rangkuman, gaya penulisan naratif, materi sangat padat, tidak mempunyai mekanisme untuk mengumpulkan umpan balik dari pemakai dan tidak memberikan saran-saran cara mempelajari materi didalamnya (Suparman, 1993).
Buku ajar merupakan unit yang lengkap yang berdiri sendiri dan terdiri atas suatu rangkaian kegiatan belajar yang disusun untuk membantu siswa mencapai sejumlah tujuan yang dirumuskan secara khusus dan jelas. Meskipun buku ajar ditujukan untuk belajar individual, namun bukan berarti guru lepas tangan tanpa memberikan bimbingan karena peran guru di sini adalah sebagai fasilitator/tutor apabila siswa mengalami kesulitan dalam mempelajari buku ajar (Nasution, 1982). Salah satu bentuk buku ajar adalah modul. Modul merupakan bahan ajar yang disusun secara sistematis dan menarik yang mencakup isi materi, metoda, evaluasi yang dapat digunakan secara mandiri, dan kebahasaannya dibuat sederhana sesuai dengan level berfikir anak (http://www. slideshare.net).

Buku ajar yang disusun dengan baik akan memberikan keuntungan baik bagi siswa maupun guru antara lain memberikan umpan baik yang banyak dan segera, sehingga siswa dapat mengetahui hasil belajarnya dan memperoleh kesempatan untuk mencapai angka tertinggi dengan menguasai bahan pelajaran secara tuntas. Wagiran (2006) melaporkan bahwa pembelajaran konstruktivistik berbantuan modul dapat mereduksi terjadinya miskonsepsi, dan meningkatkan prestasi belajar fisika.

Pembelajaran menggunakan buku ajar dapat menyesuaikan dengan karakter siswa antara lain mengenai kecepatan belajar, cara belajar dan bahan pelajaran, dengan modul interaktif juga dapat memberikan kesempatan untuk pelajaran remedial yakni memperbaiki kelemahan, kesalahan dan kekurangan siswa yang segera dapat ditemukan sendiri oleh siswa berdasarkan evaluasi secara kontinyu.

Pembelajaran dengan buku ajar memberi kesempatan yang lebih besar dan waktu yang lebih banyak kepada guru untuk memberikan bantuan dan perhatian individual pada setiap siswa yang memerlukan, serta dapat merangsang guru untuk berfikir, bersikap dan bertindak secara professional dan sekaligus dapat mengembangkan profesi.

Buku ajar ini disusun sedemikian rupa tujuannya jelas, spesifik sehingga siswa terarah untuk mencapai kompetensi pembelajaran, membimbing siswa untuk mencapai sukses melalui langkah- 
langkah yang teratur dan ini akan menimbulkan motivasi yang kuat untuk berusaha segiat-giatnya. Buku ajar yang disusun secara cermat akan memudahkan siswa untuk belajar menurut cara mereka sendiri sehingga memberikan rasa kepuasan yang lebih besar. Apalagi buku ajar yang disusun secara interaktif dapat diselingi lagu dan instrument serta warna-warna yang dapat mengurangi kejenuhan siswa dalam belajar, dan siswa dapat berinteraksi langsung buku ajar.

Perbandingan antara pembelajaran yang menggunakan buku ajar dengan yang menggunakan bukan buku ajar atau buku teks disajikan pada Tabel 1.

Sistem pembelajaran yang menggunakan buku ajar dalam bentuk modul merupakan salah satu bentuk proses pembelajaran yang demokra- tis, yaitu penghargaan terhadap kemampuan, menjunjung keadilan, menerapkan persamaan kesempatan dan memperhatikan keragaman peserta didik. Pendidik hendaknya dapat memposisikan peserta didik sebagai insan yang harus dihargai kemampuannya dan diberi kesempatan untuk mengembangkan potensinya. Oleh karena itu dalam proses pembelajaran perlu adanya suasana yang terbuka, akrab dan saling menghargai. Sebaliknya perlu dihindari suasana belajar yang kaku, penuh dengan ketegangan dan sarat dengan perintah dan instruksi yang membuat peserta didik menjadi pasif, tidak bergairah, cepat bosan dan mengalami kelelahan (Ayati, 2005).

Bentuk dan tampilan modul sangat berpengaruh terhadap motivasi belajar peserta didik. Salah

Tabel 1. Perbandingan antara pembelajaran yang menggunakan Buku Ajar dengan Buku teks

\begin{tabular}{|l|l|l|}
\hline \multicolumn{1}{|c|}{ Aspek } & \multicolumn{1}{|c|}{ Buku teks } & \multicolumn{1}{c|}{ Buku ajar } \\
\hline Tujuan & $\begin{array}{l}\text { Tidak dirumuskan secara spesifik } \\
\text { dalam bentuk kelakuan yang } \\
\text { dapat diamati dan diukur }\end{array}$ & $\begin{array}{l}\text { Dirumuskan dalam bentuk kelakuan } \\
\text { murid, apa yang diharapkan dapat } \\
\text { dilakukan setelah dijalaninya pelajaran }\end{array}$ \\
\hline $\begin{array}{l}\text { Penyajian } \\
\text { bahan } \\
\text { pelajaran }\end{array}$ & Disajikan secara kelompok kelas & $\begin{array}{l}\text { Bahan pelajaran disajikan } \\
\text { secara individual }\end{array}$ \\
\hline $\begin{array}{l}\text { Kegiatan } \\
\text { instruksional }\end{array}$ & $\begin{array}{l}\text { Kebanyakan berbentuk ceramah, } \\
\text { tugas tertulis dan media menurut } \\
\text { pertimbangan guru }\end{array}$ & $\begin{array}{l}\text { Menggunakan aneka kegiatan belajar } \\
\text { yang dapat meningkatkan proses } \\
\text { belajar berdasarkan efektifitasnya }\end{array}$ \\
\hline $\begin{array}{l}\text { Pengalaman } \\
\text { belajar }\end{array}$ & $\begin{array}{l}\text { Berorientasi pada kegiatan } \\
\text { guru dengan mengutamakan } \\
\text { proses pembelajaran }\end{array}$ & $\begin{array}{l}\text { Berorientasi pada kegiatan } \\
\text { siswa }\end{array}$ \\
\hline Partisipasi & Siswa kebanyakan bersifat pasif & $\begin{array}{l}\text { Siswa selalu aktif belajar untuk } \\
\text { menguasai bahan pelajaran }\end{array}$ \\
\hline $\begin{array}{l}\text { Kecepatan } \\
\text { belajar }\end{array}$ & $\begin{array}{l}\text { Belajar menurut kecepatan } \\
\text { yang ditentukan oleh guru }\end{array}$ & $\begin{array}{l}\text { Siswa maju menurut kecepatannya } \\
\text { masing-masing }\end{array}$ \\
\hline $\begin{array}{l}\text { Penguatan } \\
\text { (reinforce- } \\
\text { ment) }\end{array}$ & $\begin{array}{l}\text { Penguatan biasanya diadakan } \\
\text { setelah ulangan }\end{array}$ & $\begin{array}{l}\text { Penguatan sering diberikan } \\
\text { segera setelah dipelajari } \\
\text { sebagian kecil bahan pelajaran }\end{array}$ \\
\hline $\begin{array}{l}\text { Keberhasilan } \\
\text { belajar }\end{array}$ & $\begin{array}{l}\text { Keberhasilan belajar kebanyakan } \\
\text { dinilai oleh guru secara subyektif }\end{array}$ & $\begin{array}{l}\text { Keberhasilan belajar dapat dinilai secara } \\
\text { obyektif berdasarkan hasil belajar siswa }\end{array}$ \\
\hline Penguasaan & $\begin{array}{l}\text { Hanya sebagian kecil yang akan } \\
\text { menguasai bahan pelajaran } \\
\text { sepenuhnya }\end{array}$ & $\begin{array}{l}\text { Semua siswa diharapkan dapat } \\
\text { mencapai tujuan pelajaran sepenuhnya }\end{array}$ \\
\hline $\begin{array}{l}\text { Peranan } \\
\text { pengajar } \\
\text { berdasarkan tenangan dipelajari } \\
\text { penyalur pengetahuan }\end{array}$ & $\begin{array}{l}\text { Tes diadakan untuk mengukur } \\
\text { keberhasilah belajar sebagai prasyarat } \\
\text { mempelajari buku ajar tersebut }\end{array}$ \\
\hline Tes & $\begin{array}{l}\text { Pengajar berfungsi sebagai } \\
\text { pendiagnosis kekurangan siswa, } \\
\text { pemberi motivasi, pembimbing belajar }\end{array}$ \\
\hline
\end{tabular}


satu kelemahan modul tertulis adalah peserta didik merasa bosan karena harus membaca dan memahami urian materi yang luas pada modul dan biaya penggandaannya relatif mahal. Oleh karena itu diperlukan modul dalam bentuk sederhana, mudah dipahami, menarik dan biaya penggandaannya relatif lebih murah. Hal ini bisa direalisasikan melalui reduksi didaktik konsep dan dituangkan ke dalam buku ajar atau CD interaktif menggunakan software Macromedia Authorware (Adi, 2002). Macromedia Authorware dilengkapi dengan fasilitas web-packaged yang memungkinkan hasil kerja dengan Authorware dapat dikomunikasikan ke dalam dunia maya sebagai bagian dari e-learning. Pada penelitian tahap pertama ini, baru dikembangkan buku ajar non interaktif.

Penggunaan media tersebut bertujuan untuk menyampaikan informasi dan isi pelajaran agar mudah dimengerti dan dapat menarik perhatian penerima informasi tersebut. Penggunaan media dalam pembelajaran mempunyai tiga fungsi utama (Arsyad, 2003) yaitu: 1) Fungsi atensi, media menarik dan mengarahkan perhatian siswa untuk berkonsentrasi kepada isi pelajaran yang berkaitan dengan makna visual yang ditampilakan atau menyertai teks meteri pelajaran; 2) Fungsi afektif, media visual dapat dilihat seperti gambargambar atau lambang-lambang visual yang dapat menggugah emosi dan minat siswa; 3) Fungsi kongnitif, lambang visual atau gambar yang ditampilkan dalam media memperlancar pencapaian tujuan untuk memahami dan mengingat informasi atau pesan yang terkandung dalam gambar atau teks; 4) Fungsi kompensatori, media pengajaran dapat mengakomodasi siswa yang lemah dan lambat menerima dan memahami isi pelajaran yang disajikan dengan teks atau disajikan secara verbal.

Materi buku ajar kimia kelas X SMA (Depdiknas, 2004) meliputi: 1) struktur atom dan sistem periodik unsur, 2) ikatan kimia, 3) tata nama senyawa dan persamaan reaksi, 4) perhiturigan kimia, 5) larutan elektrolit dan larutan non elektrolit, 6) reaksi redoks, dan 7) hidrolarbon dan minyak bumi. Tiap bab buku ajar yang disusun dalam penelitian ini terdiri dari pendahuluan, penyajian dan penutup.
Pendahuluan, intinya adalah menyajikan informasi mengenai pembelajaran yang akan diikuti dalam modul, sehingga akan memperoleh gambaran singkat tentang buku ajar tersebut, yaitu: 1) Deskripsi singkat tentang isi buku ajar yang ditulis dalam satu atau dua paragraph; 2) Relevansi, berisi hal-hal: (a) Kaitan buku ajar dengan pengalaman atau pengetahuan yang telah dimiliki siswa; (b) Manfaat buku ajar bagi siswa dalam kehidupan sehari-hari; dan (c) Kegunaan bagi siswa jika mempelajari buku ajar mata pelajaran lain (apabila buku ajar tersebut terkait dengan buku ajar lain)

\section{Penyajian}

1) Judul kegiatan belajar

2) Tujuan pembelajaran yang berkaitan dengan kegiatan belajar

3) Uraian/penjelasan secara rinci mengenai materi disertai ilustrasi seperti gambar, bagan, grafik, dan contoh.

4) Latihan yang berbentuk perintah yang harus dilakukan siswa, bisa berupa tugas, permasalahan, soal-soal uji diri/Self Assesment Question (SAQ) atau praktik yang disertai petunjuk secara bertahap.

\section{Penutup}

(1) Uji kemampuan berisi soal tes

(2) Tindak lanjut yaitu kegiatan yang harus dilakukan siswa setelah mengerjakan uji kemampuan.

Buku ajar yang baik harus memeperhatikan perkembangan ilmu pengetahuan dan teknologi, serta pengalaman masa kini. Beberapa aspek standar yang harus dipenuhi sebuah buku ajar meliputi keterukuran dan ketercapaian (achievable), kepraktisan (practical) dan menumbuhkan kecakapan hidup (life-skill). Standarisasi ini mencakup aspek isi atau materi pelajaran, penyajian materi, penggunaan bahasa atau keterbacaan dan aspek grafika. Dalam penyusunan bahan ajar berdasarkan kaidah-kaidah keilmuan, dapat dipertanggungjawabkan kebenarannya, sesuai dengan standar kurikulum nasional dan standar kompetensi internasional (Alwasilah, 2005). 


\section{Reduksi Didaktik}

Reduksi Didaktik berasal dari bahasa Jerman "Didaktische Reduktion", terdiri dari kata "Reduksi" berarti pengurangan dan "Didaktik' diartikan sebagai ilmu pengajaran. Karakteristik reduksi didaktik antara lain (1) merupakan jembatan antara perkembangan IPTEK dengan materi pengajaran (2) merupakan salah satu alternatif untuk memecahkan masalah kesulitan terlalu banyaknya materi pengajaran dalam satuan waktu. Reduksi Didaktik bertujuan mengurangi tingkat kesulitan materi pengajaran baik secara kualitatif ataupun kuantitatif dengan jalan materi tersebut dibuat sesederhana mungkin sehingga lebih mudah dipelajari oleh peserta didik (Anwar, 1995).

Reduksi didaktik harus dilakukan secara didaktik-psikologis, artinya selain mempertimbangkan aspek pembelajaran juga aspek psikologis. Reduksi didaktik materi kimia dapat dilakukan melalui penyederhaaan istilah, penyederhanaan konsep, penggunaan simbul, gambar, dan ilustrasi yang mudah dipahami oleh siswa, yang selanjutnya diterapkan pada sajian informasi buku ajar.

Proses reduksi didaktik juga harus mendasarkan pada tingkat perkembangan psikis dan umur peserta didik, sebab setiap anak didik pada tingkat perkembangan tertentu mempunyai cara tersendiri yang khas di dalam memandang, menggambarkan dan menjelaskan konsep untuk mengurangi tingkat kesulitan materi pelajaran tanpa mengurangi tingkatan cakupan ilmiahnya. Menurut Piaget terdapat empat tahap perkembangan kognitif seseorang yakni sensorimotor (dari lahir sampai 2 tahun), praoperasional (umur 2-7 tahun), operasi kongkrit (umur 7-11 tahun) dan operasi formal (umur 11 atau lebih) (Nur 1998). Berdasarkan teori tersebut siswa tingkat SMA berada pada tahap operasi formal, dimana siswa telah mampu berfikir abstrak sehingga daya analisisnyapun mulai berkembang. Aspek psikologi belajar yaitu intelligensi dan psikologi perkembangan tersebut harus dipertimbangkan dalam melakukan reduksi didaktik mata pelajaran kimia.

\section{Buku Ajar Berbasis Reduksi Didaktik Untuk Pembelajaran Kimia}

Terdapat beberapa penyebab terjadinya hambatan dalam mempelajari ilmu kimia antara lain kesulitan memahami istilah, kesulitan memahami konsep kimia, dan kesulitan matematis (Middlecamp \& Kean, 1985; Arifin, 1995).

1) Kesulitan memahami istilah

Kesulitan ini timbul karena kebanyakan siswa hanya hafal akan istilah dan tidak memahami dengan benar maksud dari istilah tersebut. Oleh karena itu diperlukan reduksi didaktik melalui penyederhanaan istilah yang sesuai dengan tingkat pengetahuan siswa.

2) Kesulitan memahami konsep kimia Kesulitan ini akibat sebagian besar konsep kimia bersifat abstrak, yang memerlukan kemampuan berfikir formal untuk memahaminya. Sementara tingkat berfikir formal siswa masih relatif belum memadai. Seperti kesulitan menggambarkan bagaimana terjadinya reaksi kimia, bagaimana elektron dilepaskan atau digunakan bersama ketika atom-atom melakukan ikatan kimia, bagaimana reaksi berlangsung di katoda atau anoda? Dengan demikian memerlukan ilustrasi atau pengamatan gejala misalnya melalui eksperimen. Melalui kegiatan eksperimen, siswa akan mendapatkan konsep yang dipelajari melalui pengalaman langsung, mengamati, menafsirkan, meramalkan serta mengajukan pertanyaan-pertanyaan selama kegiatan praktikum berlangsung. Masykur dkk. (1995) melaporkan bahwa pengalaman kerja laboratorium berpengaruh secara langsung pada kemampuan intelektual dan kemampuan proses ilmiah. Kemampuan proses ilmiah dan kemampuan intelektual ini berpengaruh langsung terhadap terhindarnya kesalahan pemahaman pada konsep. Masalahnya adalah apakah semua konsep kimia dapat dieksperimenkan?

Konsep struktur atom dan ikatan kimia merupakan salah satu contohnya. Konsep ini tidak mungkin diajarkan melalui pendekatan eksperimen seperti halnya konsep larutan. Selain karena kerumitan konsep, juga tidak tersedianya alat dan prosedur yang sesuai dengan kemampuan siswa. Yang paling mungkin adalah melakukan reduksi didaktik dalam bentuk pengkonkritan konsep melalui analogi, gambar atau penggunaan media baik yang bersifat konvensional seperti buku ajar, 
maupun yang berbasis komputasi seperti program macromedia flash, yang umumnya untuk visualisasi dan animasi (Jeprie, 2004) dan macromedia authorware yang umumnya untuk buku ajar interaktif (Adi, 2002).

Hasil penelitian Asian Develompment Bank (Ibrahim, 2000) menunjukkan bahwa pembelajar di Indonesia $60 \%$ berkarakter contextual artinya siswa baru dapat belajar bila guru/ dosen membantu mengkaitkan pembelajaran dengan hal-hal yang kongkrit atau dengan fakta kehidupan. Furio dan Calatayud (1996) menemukan bahwa sebagian besar terjadinya salah konsep (misconception) pada pembelajaran geometri dan polaritas molekul pada siswa SMA adalah karena kesulitan menvisualisasikan bentuk tiga dimensi molekul yang merupakan konsep abstrak. Hal ini menunjukkan betapa pentingnya ketersediaan media pembelajaran termasuk buku ajar yang mampu menyederhanakan konsep sekaligus menjadikan konsep semakin kongkrit dan mudah dipahami oleh siswa, selain pemilihan model pembelajaran sains yang tepat.

3) Kesulitan matematis

Kesulitan ini muncul akibat banyaknya konsep kimia yang melibatkan kemampuan analisis secara matematis, sementara umumnya siswa memiliki kemampuan analisis matematis yang relatif kurang.

Kesulitan mempelajari kimia khususnya di kelas $X$ perlu mendapatkan perhatian, karena pemahaman yang baik terhadap konsep kimia di kelas $X$ akan mempengaruhi motivasi dan pemahaman siswa pada kelas-kelas berikutnya. Penggunaan materi ajar berbasis reduksi didaktik untuk materi struktur atom, sistem periodik unsur dan ikatan kimia di kelas $X$ dapat meningkatkan pemahaman siswa secara signifikan (Anwar, 2006). Implementasi materi ajar reduksi didaktik pada materi laju reaksi di kelas XI, menunjukkan bahwa hasil belajar siswa kelas yang menggunakan materi berbasis reduksi didaktik lebih tinggi dibanding yang tidak menggunakan pendekatan reduksi didaktik. (Febrianti, 2005). Fakta di atas menunjukkan bahwa pendekatan Reduksi Didaktik dalam menyajikan materi kimia pada proses pembelajaran kimia dapat mengatasi kesulitan siswa dan mempunyai pengaruh positif terhadap peningkatan hasil belajar.

Berdasarkan karakteristik buku ajar dan pendekatan reduksi didaktik maka perlu dikembangkan buku ajar kimia berbasis reduksi didaktik yang diharapkan diharapkan selain mempermudah siswa memahami konsep kimia juga makin meningkatkan motivasi belajarnya.

\section{Metode Penelitian}

Populasi penelitian adalah 13 SMA Negeri yang ada di kota Banjarmasin, sedangkan sampel diambil secara stratified random sampling sebanyak 3 sekolah. Tiga sekolah terpilih masingmasing mewakili tiga kategori yakni sekolah favorit, sedang dan tidak favorit berdasarkan persepsi stakeholder dan skor akreditasi. Selanjutnya tiap sekolah diambil secara acak masing-masing satu kelas sebagai kelas uji coba buku ajar berbasis reduksi didaktik.

Instrumen tes hasil belajar dikembangkan berdasarkan kurikulum satuan pendidikan 1996 (KTSP) (Depdiknas, 2004) dan diuji validitasnya. Untuk mengetahui kualitas buku ajar yang dihasilkan digunakan instrumen validasi, yang akan diisi oleh validator yang terdiri dari dosen pendidikan kimia dan guru. Selain itu digunakan angket untuk mengetahui respon/pendapat siswa terhadap buku ajar yang digunakan pada pembelajaran kimia. Proses pembelajaran diobservasi menggunakan lembar observasi untuk memastikan digunakannya buku ajar secara benar dan untuk mengontrol bahwa pembelajaran sudah susuai skenario, sehingga dapat diketahui dampak penggunaan buku ajar terhadap pemahaman siswa.

Data hasil penelitian yang meliputi validitas buku ajar, respon siswa dan hasil belajar siswa, dianalisis secara deskriptif berdasarkan indikator kualitas atau kelayakan buku ajar. Buku ajar dikatakan layak digunakan jika: (1) Skor validasi maupun respon siswa terhadap buku ajar dalam kategori baik atau sangat baik (2) Ketuntasan belajar siswa: sebanyak $80 \%$ atau lebih siswa yang menggunakan buku ajar ini mencapai tingkat penguasaan $\geq 65$. Instrumen validasi maupun respon siswa dibuat berdasarkan skala Likert dari skor 0 (sangat tidak baik) hingga 5 (sangat baik). 


\section{Hasil Penelitian dan Bahasan Hasil Penelitian Validasi buku ajar}

Sebelum digunakan dalam proses pembelajaran, buku ajar divalidasi oleh dosen dan guru kimia. Hasil validasi disajikan pada Gambar 1 dan Gambar 2. Evaluasi atau validasi buku ajar oleh validator yang terdiri dari seorang dosen pendidikan kimia dan 4 orang guru pendidikan kimia, dilakukan terhadap 3 aspek yakni isi, instruksional dan teknis. Hasil validasi buku ajar menunjukkan bahwa dari seluruh aspek yang divalidasi menunjukkan kualifikasi sangat baik. Artinya buku ajar kimia kelas $X$ ini layak digunakan dalam pembelajaran kimia.

\section{Respon Siswa terhadap Buku Ajar}

Setelah menggunakan buku ajar kimia berbasis reduksi didaktik siswa diberikan angket untuk mengetahui apakah buku ajar ini membantu

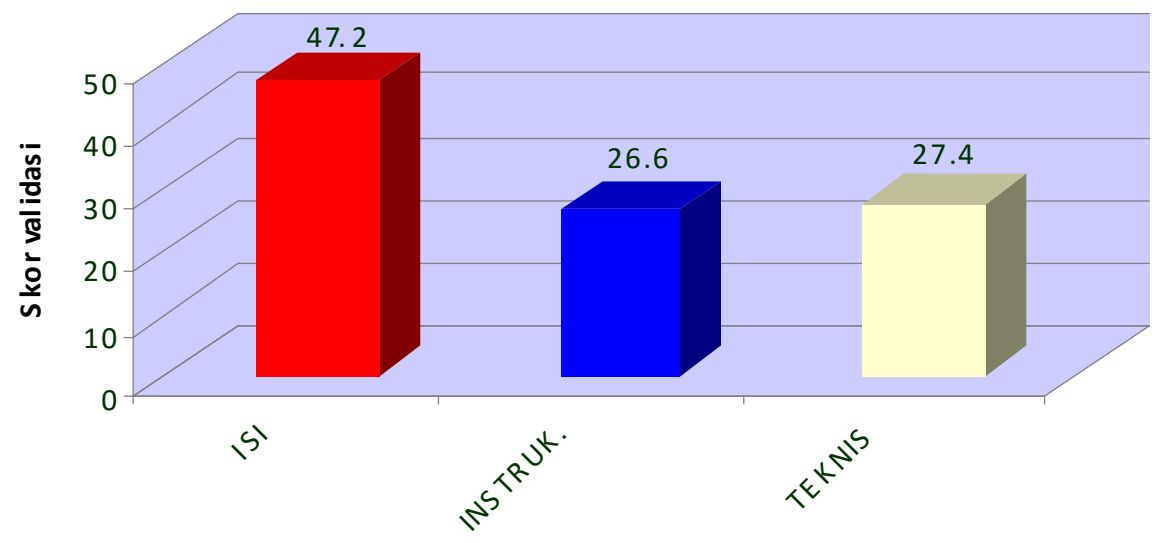

Aspek buku ajar

Gambar 1. Hasil validasi tiap aspek buku ajar

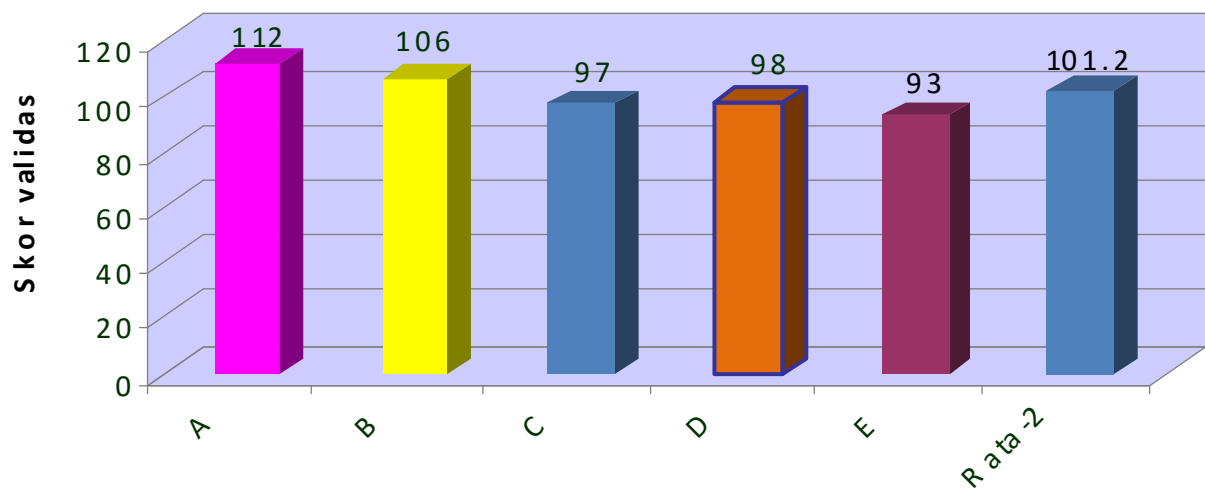

Valida tor

Gambar 2. Hasil validasi seluruh aspek buku ajar

\section{Kreteria Validasi}

Aspek total

98-116 = sangat baik

$79-97=$ baik

$60-78=$ sedang

41-59= kurang

$22-40=$ sangat kurang Aspek isi

47-55 = sangat baik

38-46 = baik

29-37 = sedang

20-28 = kurang 11-19= sangat kurang
Aspek Instruktional dan Teknis

26-30 = sangat baik

21-25 = baik

$16-20$ = sedang

11-15 = kurang

$6-10=$ sangat kurang 
siswa dalam memahami konsep. Responden adalah siswa kelas uji coba dengan jumlah total 122 siswa. Respon siswa terhadap buku ajar disajikan pada Gambar 3.

Gambar 3 menunjukkan bahwa secara umum respon siswa terhadap buku ajar dalam kategori baik. Hal ini berarti, siswa merasa buku ajar ini dapat membantu memahami konsep, menarik dan memotivasi belajar secara mandiri. Dari sudut pandang siswa dapat dikatakan bahwa buku ajar ini layak digunakan dalam pembelajaran kimia.

\section{Hasil Belajar Siswa}

Hasil belajar kimia siswa pada pembelajaran dengan menggunakan buku ajar berbasis reduksididaktik yang diukur melalui tes-1 (struktur atom dan sistem periodik unsur) dan tes-2 (ikatan kimia) disajikan pada Gambar 4 dan ketuntasan belajarnya disajikan pada gambar 5 .

Gambar 4 dan 5 menunjukkan bahwa hasil belajar siswa cukup baik yakni mencapai rata-rata 72,86, dan mencapai ketuntasan belajar secara klasikal, yakni $80,2 \%$. Dengan demikian berdasarkan data hasil belajar dapat dikatakan bahwa buku ajar ini layak digunakan dalam pembelajaran kimia kelas $X$.

\section{Bahasan}

Tiga dari lima validator memberikan catatan dan saran bahwa kedalaman/ketercukupan materi perlu ditingkatkan. Saran ini tepat jika dilihat dari sudut guru, dimana pengetahuan dan pemahaman terhadap konsep kimia secara umum sangat baik, namun menjadi bermasalah jika ditinjau dari segi siswa yang memiliki konsep dasar kimia belum memadai. Hasil penelitian Nisa dkk. (2006) menunjukkan bahwa salah satu masalah siswa adalah kesukaran memahami konsep kimia karena banyak melibatkan konsep yang bersifat abstrak dan padatnya materi pelajaran. Buku ini sengaja dirancang dengan pendekatan reduksi didaktik baik secara kualitatif maupun kuantitatif terhadap materi pelajaran untuk memudahkan siswa memahami konsep. Reduksi didaktik secara kuantitatif

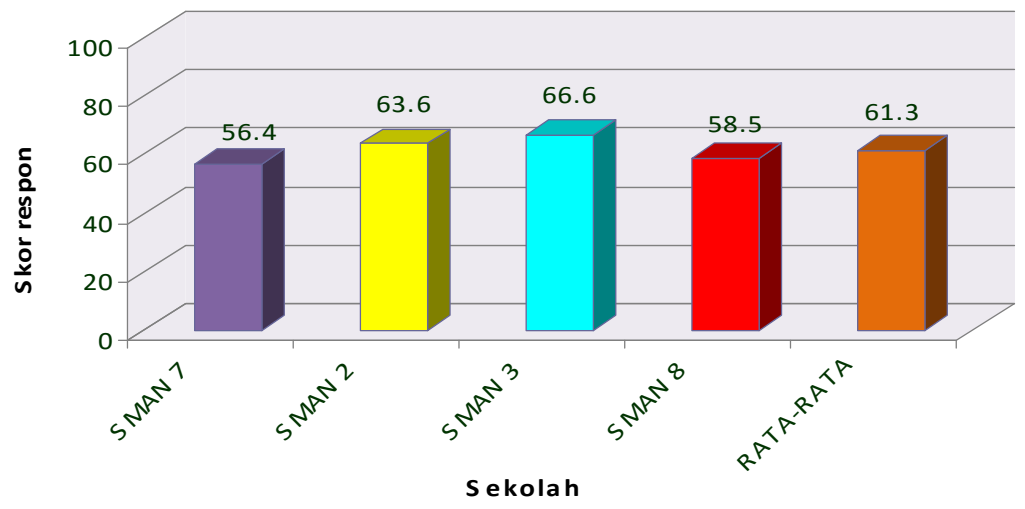

Gambar 3. Respon siswa terhadap buku ajar

\section{Kreteria Respon}

$65-77=$ sangat baik; $52-64=$ baik; $39-5=$ sedang; $26-38=$ kurang; $13-25=$ sangat kurang

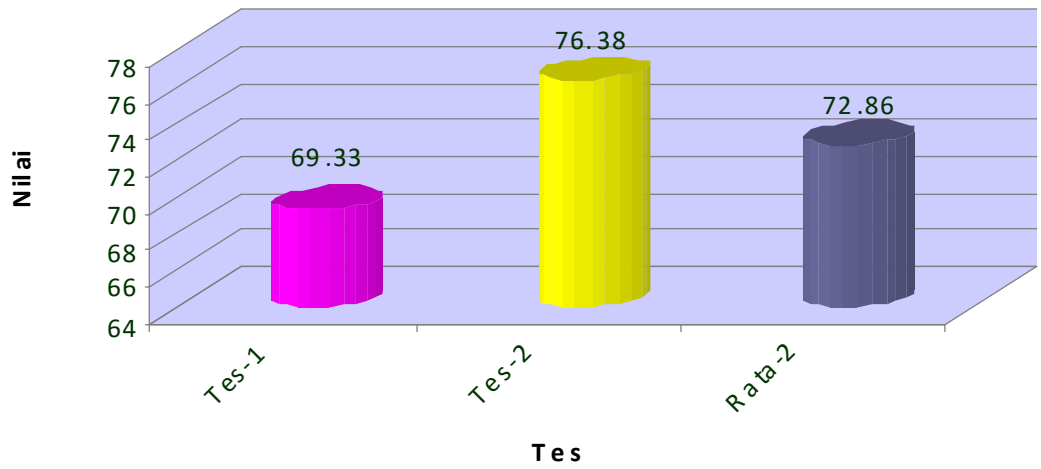

Gambar 4. Rata-rata hasil belajar siswa 


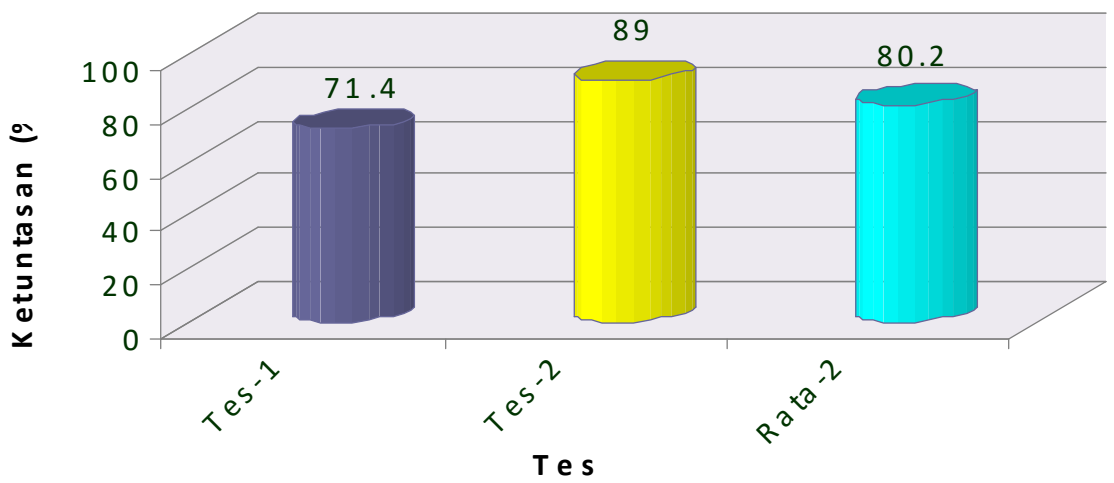

Gambar 5. Ketuntasan hasil belajar siswa

maupun kualitatif ini dilakukan melalui penyederhanaan konsep, istilah, penggunaan simbol, gambar, dan ilustrasi. Dengan demikian buku ajar ini dirancang sesederhana mungkin untuk menghindari beratnya sajian konsep seperti yang ada dalam buku-buku teks kimia pada umumnya, agar siswa termotivasi untuk mendalami kimia.

Berdasarkan karakteristik modul/buku ajar yang baik (Depdiknas, 2003) yakni self instructional, self contained, stand alone, adaptif dan user friendly, dan hasil validasi buku ajar ini, pada dasarnya rancangan buku ajar yang disajikan telah memenuhi kaidah buku ajar yang baik. Self instructional, artinya buku ajar harus memberi kesempatan dan mengakibatkan siswa belajar secara mandiri. Self contained, artinya seluruh materi pelajaran dari satu kompetensi atau subkompetensi yang dipelajari terdapat dalam satu modul yang utuh. Stand alone, artinya modul yang dikembangkan tidak tergantung atau harus digunakan bersama-sama dengan buku ajar lain. Adaptif, artinya buku ajar dapat menyesuaikan dengan perkembangan ilmu pengetahuan dan materi ajarnya dapat digunakan sampai kurun waktu tertentu. User friendly, artinya buku ajar harus "bersahabat" dengan siswa, sangat sederhana, mudah dipahami, mudah diakses, dan menarik untuk dibaca.

Meskipun buku ajar telah dirancang untuk tujuan di atas, seperti dengan adanya petunjuk penggunaan buku, tujuan pembelajaran, adanya evaluasi diri, uji kompetensi dan bahkan tindak lanjut pasca pembelajaran, namun pada saat menggunakan siswa belum secara optimal memperhatikan maksud tersebut. Hal ini terlihat dari respon siswa dimana terdapat dua indikator yang memerlukan peningkatan dalam pengguna- an buku ajar, karena direspon dalam kategori cukup (dibawah indikator lain yang umunya kategori baik). Indikator tersebut yaitu 1 ) membaca/memahami petunjuk buku ajar dan 2) mengikuti saran dalam tindak lanjut. Tampaknya siswa masih terbiasa dengan buku-buku teks yang umumnya digunakan, dan terbiasa dengan model belajar yang sangat tergantung pada instruksi guru. Oleh karena itu pada tahap awal guru harus menekankan hal tersebut pada siswa sehingga pembelajaran berlangsung optimal. Namun demikian hampir semua siswa menyatakan bahwa buku ajar ini sangat diperlukan dalam pembelajaran kimia di kelas $X$ SMA.

Gambar 4 menunjukkan bahwa tingkat pemahaman siswa pada materi 1 yakni struktur atom dan sistem periodik dari seluruh sekolah sampel lebih rendah dibandingkan materi 2 tentang ikatan kimia dan tatanama senyawa kimia. Konsep tentang struktur atom dan sistem periodik banyak melibatkan hafalan dan pemahaman tentang logika temuan-temuan tentang atom dan partikel penyusun, yang memerlukan daya analisis siswa. Respon siswa yang sedikit lebih rendah tentang penjelasan dan bahasa, memberi gambaran bahwa siswa mengalami kesulitan dalam mengikuti analisis ilmiah ini. Oleh karena, itu meskipun bahasa sudah dalam kategori sederhana, perlu dilakukan penyederhanaan lagi pada edisi buku ajar berikutnya. Sementara materi 2 banyak melibatkan aplikasi konsep yang didasari oleh pemahaman pada materi 1.

Proses pembelajaran seluruh kelas uji coba dalam penelitian ini, menggunakan metode ceramah-tanya jawab, sehingga pengaruh penggunaan buku ajar dapat diamati dengan lebih 
akurat dan bukan pengaruh model atau metode yang diterapkan. Ketuntasan belajar secara klasikal yang baik yakni $80,2 \%$ ini, sesungguhnya masih mungkin dioptimalkan jika pembelajaran menggunakan metode atau pendekatan yang lebih mengoptimalkan keterlibatan dan aktivitas siswa, seperti pendekatan kooperatif (Ibrahim, dkk. 2000, Wagiran, 2006), seperti Jigsaw, Team Game Tournament, Student Teams Achievement Division dan lain-lain, yang telah terbukti dapat meningkatkan aktivitas dan hasil belajar siswa.

Hasil penelitian ini sejalan dengan penelitian Febrianti (2005) yang menunjukkan bahwa hasil belajar siswa kelas XI. IPA SMA Negeri 26 Bandung pada materi laju reaksi yang menerapkan reduksi didaktik lebih tinggi dibanding yang tidak menggunakan pendekatan reduksi didaktik. Fakta di atas menunjukkan bahwa pendekatan Reduksi Didaktik dalam proses belajar mengajar mempunyai pengaruh positif terhadap peningkatan hasil belajar siswa.

Ditinjau dari indikator keberhasilan penelitian yakni indikator kualitas atau kelayakan buku ajar, penelitian ini dapat dikatakan berhasil. Adapun indikator kualitas atau kelayakan buku meliputi: (1) skor validasi buku ajar yang diberikan oleh validator maupun respon siswa terhadap buku ajar dalam kategori sangat baik (2) keuntasan belajar siswa: $80,2 \%$ sedikit di atas indikator minimal yakni $\geq 80 \%$. Artinya $80,2 \%$ atau lebih siswa yang diajar menggunakan buku ajar ini mencapai tingkat penguasaan $\geq 65$.

Penelitian ini baru dapat memberikan gambaran kelayakan buku ajar untuk Sekolah Menengah Atas Negeri khususnya di kota Banjarmasin, sehingga masih diperlukan uji coba dalam skala yang lebih luas termasuk untuk sekolah-sekolah swasta dengan latar belakang siswa yang lebih bervariasi. Selain itu buku ajar ini juga perlu dikembangkan menjadi buku ajar interaktif menggunakan software yang mampu meningkatkan kemudahan akses, daya tarik, motivasi dan pemahaman siswa terhadap konsep kimia. Salah satunya adalah program Macromedia Authorware.

Pengembangan buku ajar menjadi buku interaktif akan menjadikan harganya makin terjangkau, khususnya bagi sekolah-sekolah yang telah memiliki laboratorium komputasi yang cukup memadai. Hampir semua SMA Negeri di kota Banjarmasin telah memiliki laboratorium yang mampu menampung minimal satu kelas siswa dengan perlengkapan komputer yang sangat memadai (BAP S/M Propinsi Kalsel, 2008), apalagi di kota-kota lain yang telah lebih maju. Perkembangan teknologi informasi dalam pendidikan yang cukup pesat, juga memberi peluang lebih baik bagi media interaktif ini menjadi bagian dari E-learning. Dengan demikian materi kimia makin mudah diakses oleh siswa secara luas, pembelajaran kimia makin menarik dan memberi kesempatan siswa untuk belajar lebih mandiri.

Sebelum dikembangkan ujicoba dengan sampel yang lebih luas dan menjadi media interaktif, berdasarkan masukan dari guru dalam ujicoba dan respon siswa pengguna buku ajar, perlu dilakukan: 1) revisi terhadap kesalahan redaksional; 2) lebih menyederhanakan lagi bahasa indonesia yang digunakan; dan 3) meningkatkan tampilan fisik buku ajar sehingga lebih menarik dan memotivasi siswa untuk membaca.

\section{Simpulan dan Saran Simpulan}

Buku buku ajar kimia kelas $\mathrm{X}$ berbasis reduksi didaktik yang dihasilkan dalam penelitian ini, layak digunakan dalam pembelajaran berdasarkan indikator: validitas buku ajar oleh validator dalam kategori sangat baik, respon siswa terhadap buku ajar dalam kategori baik, dan ketuntasan belajar siswa secara kalisikal mencapai $80,2 \%$

\section{Saran}

Pertama, Saat menggunakan buku ajar berbasis reduksi didaktik ini dalam pembelajaran, guru perlu meningkatkan kemandirian siswa, meng-arahkan siswa agar mengikuti panduan penggunaan buku khususnya tentang penyelesaian soal-soal dalam self assesment questions (SAQ) dan tindak lanjut pasca belajar, sehingga mencapai hasil belajar yang optimal.

Kedua, Perlu dilakukan ujicoba yang melibatkan karakter siswa yang bervariasi, misalnya untuk siswa-siswa SMA swasta dan Madrasah Aliyah Negeri/Swasta, untuk meningkatkan kualitas buku ajar dan memenuhi sifat self instructional dan user friendly. 
Ketiga, Perlu pengembangan buku ajar menjadi buku ajar interaktif seiring dengan perkembangan e-learning, sehingga menghasilkan buku ajar yang makin murah, menarik, mudah dipelajari, diminati siswa dan terakses secara luas.

\section{Pustaka Acuan}

---. Pengembangan Bahan Ajar. http://www.slideshare.net/smpbudiagung/pengembangan bahan ajar. Diakses tanggal 19 Mei 2009.

Adi, H.S. 2002. Macromedia Authorware. Yogyakarta: Andi Offset.

Alwasilah, A.C. 2005. Menaksir Buku Ajar. http://rakyat. com/cetak/2005/0505/26/0801/ .htmpascetak/0604/24/humaniora/2603446.htm.

Anwar, A. 1996. Reduksi Materi Pengajaran Struktur Atom, Sistem Periodik Unsur dan Ikatan Kimia, dalam meningkatkan Pemahaman Konsep. Jakarta: Proseding Seminar nasional HEDS.

Arifin, M. 1995. Pengembangan Program Pengajaran Bidang Studi Kimia. Surabaya: Airlangga University Press.

Arsyad, A. 2005. Media Pembelajaran. PT. Jakarta: Raja Grafindo Persada.

Ayati, D. 2005. Upaya Memotivasi Siswa pada Pembelajaran Keterampilan Komputer dan Pengolahan Informasi dengan Modul Interaktif, Banjarmasin: Disdik Propinsi Kalsel.

Badan Akreditasi Propinsi 2008. Laporan Visitasi SMA/SMK. Banjarmasin: BAP S/M Propinsi Kalimantan Selatan.

Depdiknas. 2003. Buku Pedoman Penulisan Modul. Jakarta: Direktorat Pendidikan Menengah Kejuruan Ditjen Dikdasmen.

Depdiknas. 2004. Kurikulum 2004, Standat Kompetensi Mata Pelajaran Kimia Sekolah Menengah Atas dan Madrasah Aliyah. Jakarta: Depdiknas.

Febrianti, L. 2005. Pengaruh Reduksi Didaktik dalam Pembelajaran Kimia terhadap Hasil Belajar Siswa pada Subpokok Bahasan Faktor-Faktor yang Mempengaruhi Laju Reaksi. http://digilip. upi. edu/ union/indek, php//record/view/6885.

Furio, C dan Calatayud, M. L. 1996. Difficulties with the Geometry and Polarity of Molecule. J. Chem. Educ. $73:$ 36-41.

Ibrahim, M., Rachmadiarti, F., Nur, M., dan Ismono. 2000. Pembelajaran Kooperatif. Unessa University Press, Surabaya.

Indrianto, B. 2002. Arah Kebijakan Pendidikan dalam Menunjang Desentralisasi Pengelolaan Pendidikan. Banjarmasin: Proseding Seminar Nasional ISP Kalsel.

Jeprie, M. 2004. Makromedia Flash MX 2004. Jakarta: PT. Elex Media Komputindo Kelompok Gramedia.

Masykur, K., Sutarman, Asim dan Suyudi, A., (1995). Kesalahan Pemahaman pada Konsep dalam Belajar Fisika Bagi Siswa SMAN di Jawa Timur Ditinjau dari Beberapa Faktor Internal dan Eksternal yang Mempengaruhinya, Jurnal I/mu Pendidikan, 3: 261-273.

Middlecamp, C. dan Kean, E. 1985. Panduan Belajar Kimia Dasar. Jakarta: Gramedia.

Nasution, S. 1982. Berbagai Pendekatan dalam Proses Belajar dan Mengajar. Jakarta: PT. Bina Aksara

Nisa, N., Sholahuddin, A., dan Sunarti 2005. Analisis Tingkat Kesukaran Materi Pokok Kimia Kelas X SMA Negeri di Kota Banjarmasin Tahun Pelajaran 2005/2006, Laporan Penelitian. Banjarmasin: Unlam.

Suparman, A. 1993. Materi Pelatihan Applied Aproach untuk Dosen. Jakarta: PAU- PPAI-UT.

Wagiran. 2006. Meningkatkan Kreativitas Mahasiswa dan Reduksi Miskonsepsi melalui Pembelajaran Konstruktivistik Model Kooperatif Berbantuan Modul. Jurnal Ilmu Pendidikan, 13:25-32. 